\title{
Comments on Space Randomized Clinical Trial by Krebs et al
}

\section{TO THE EDITOR:}

We would like to comment on a manuscript published in JAMA entitled "Effect of opioid vs nonopioid medications on pain-related function in patients with chronic back pain or hip or knee osteoarthritis pain: The SPACE randomized clinical trial." This manuscript has been termed "SPACE randomized clinical trial" (1). This is a pragmatic trial showing that nonopioid treatments are equivalent or even superior to opioid therapy. The following limitations are important to consider in terms of SPACE's generalizability.

Firstly, it is unclear what specific drug therapy the patients were on. The patients pain was noted as moderate to severe despite analgesic use leading us to presume that patients were on nonsteroidal antiinflammatory agents or Tramadol. The selection yielded only 1 out of 19 patients assessed, showing the difficulties with application of such data in practical terms.

Second, SPACE is applicable specifically in the primary care setting. Patients presenting for chronic pain management have presumably failed the treatments utilized in this manuscript, prior to embarking on opioids. That said, morphine doses appear to be high for most primary care settings (2).

Third, the authors have indicated that Tramadol is a nonopioid; however, Tramadol is a controlled substance and binds to $\mu$-opioid receptors. Tramadol has been described to be equivalent to codeine with a similar side effect profile to other opioids, including abuse patterns $(2,3)$.

Fourth, an analysis of the proportion of patients with at least $30 \%$ reduction of pain intensity, or pain interference scales would have been helpful. At present, it is difficult to draw meaningful conclusions in reference to the effectiveness in terms of individual patients.

Fifth, the majority of patients were males vs. the general population where opioid recipients are more commonly female (4). Other parameters of note, low back pain in $65 \%$ of patients, pre-randomization treatment group preferences were $25 \%$ with opiates $/ 44 \%$ in nonopioids and opioid safety/effectiveness was shown to be perceived by a very small number of patients. This data is in contrast to the usual presentation of patients to pain management clinics with primary preference for opioids, unusually high perceived safety and expectations of their effectiveness over other techniques and non-opioid drug therapy.

Sixth, patient misuse measures including urine drug testing has not been performed per opioid guidelines (3). The authors have reported almost $30 \%$ potential misuse measures in each group. Authors also have not provided the data in reference to the number of patients in each category of drug intake. Uncontrolled outside treatment may influence the outcomes and due to infrequent and known time period drug testing. Potential misuse may thus have been missed in the analysis.

Despite the above limitations, the manuscript provides excellent real world data re: limitations of opioid therapy in the primary care setting.

Laxmaiah Manchikanti, MD

Clinical Professor

Anesthesiology and Perioperative Medicine

University of Louisville, Louisville, Kentucky

Professor of Anesthesiology-Research

Department of Anesthesiology, School of Medicine

LSU Health Sciences Center, New Orleans, Louisiana

Medical Director,

Pain Management Center of Paducah

2831 Lone Oak Road

Paducah, KY 42003

Phone: 270-554-8373 ext. 101

Fax: 270-554-8987

drlm@thepainmd.com

Ramsin Benyamin, MD

Medical Director

Millennium Pain Center, Bloomington, IL

Clinical Assistant Professor of Surgery

College of Medicine, University of Illinois,

Urbana-Champaign, IL

1015 S. Mercer

Bloomington, IL 61701

ramsinbenyamin@yahoo.com

Joshua A. Hirsch, MD

Vice Chief: Interventional Care 
Massachusetts General Hospital Associate Professor of Radiology, Harvard Medical School Affiliate Senior Research Fellow:
Neiman Health Care Policy Institute

55 Blossom St., Gray 241B

Boston, MA 02114

hirsch@snisonline.org

\section{References}

1. Krebs EE, Gravely A, Nugent S, et al. Effect of opioid vs nonopioid medications on pain-related function in patients with chronic back pain or hip or knee osteoarthritis pain: The SPACE randomized clinical trial. JAMA 2018; 319:872-882.

2. Dowell D, Haegerich TM, Chou R. CDC guideline for prescribing opioids for chronic pain--United States, 2016. JAMA 2016; 315:1624-1645.

3. Manchikanti L, Kaye AM, Knezevic NN, McAnally $H$, Trescot AM, Blank S,
Pampati V, Abdi S, Grider JS, Kaye AD, Manchikanti KN, Cordner HJ, Gharibo CG, Harned ME, Albers SL, Atluri S, Aydin SM, Bakshi S, Barkin R, Benyamin RM, Boswell MV, Buenaventura RM, Calodney AK, Cedeno DL, Datta S, Deer TR, Fellows B, Galan V, Grami V, Hansen $H$, Helm S 2nd, Justiz R, Koyyalagunta D, Malla Y, Navani A, Nouri K, Pasupuleti $\mathrm{R}$, Sehgal N, Silverman SM, Simopoulos TT, Singh V, Slavin KV, Solanki DR, Staats PS, Vallejo R, Wargo BW, Watanabe
A, Hirsch JA. Responsible, safe, and effective prescription of opioids for chronic non-cancer pain: American Society of Interventional Pain Physicians (ASIPP) guidelines. Pain Physician 2017; 20:S3S92.

4. Manchikanti L, Cash KA, Malla Y, Pampati $V$, Fellows B. A prospective evaluation of psychotherapeutic and illicit drug use in patients presenting with chronic pain at the time of initial evaluation. Pain Physician 2013; 16:E1-E13. 